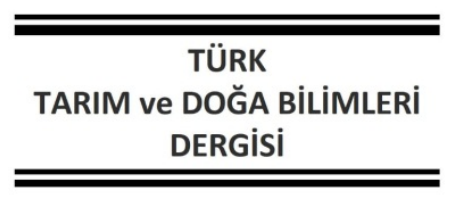

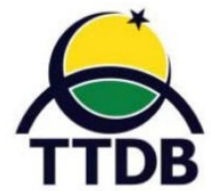

www.dergipark.gov.tr/turkjans

Araştırma Makalesi

\title{
'Guldar’ Domatesinin Coğrafi İşaret Almasına Yönelik Yürütülen Arazi ve Laboratuvar Çalışmaları
}

\author{
Nusret ÖZBAY
}

Bingöl Üniversitesi, Ziraat Fakültesi, Bahçe Bitkileri Bölümü, Bingöl

Sorumlu Yazar: nozbay@bingol.edu.tr

Geliş Tarihi: 21.03.2021 Düzeltme Geliş Tarihi: 09.04.2021 Kabul Tarihi: 09.04.2021

\section{$\overline{0 ̈ z}$}

Coğrafi işaret belirgin bir özelliği, namı veya diğer özellikleri bakımından menşeinin bulunduğu yöre, alan, bölge veya ülke ile bütünleşmiş ürünü gösteren bir işarettir. Tüm ürünlerde olduğu gibi bitkisel ürünlerde de coğrafi işaret alınmasına yönelik çalışmaların yapılması çok önemlidir. Bu araştırma, Bingöl'de 'Guldar' ismiyle anılan köy domatesinin coğrafi işaret almasına yönelik olarak, 2019 yılı vejetasyon periyodunda, 7 adet sofralık domates genotipinin morfolojik, fizyolojik, kimyasal ve verim özelliklerinin belirlenmesi amacıyla yürütülmüştür. Araştırma iki farklı lokasyonda açık tarla koşullarında, tesadüf blokları deneme desenine göre üç tekerrürlü olarak yürütülmüştür. Domates genotiplerinin karşılaştırılmasında, tohumlarda çimlenme oranı, ilk çiçeklenme, ilk meyve tutumu ve ilk hasada kadar geçen süre, klorofil içeriği (SPAD), ortalama meyve eni, ortalama meyve boyu, meyve indeksi, meyvede sap çukuru genişliği, ortalama meyve sayısı, ortalama meyve ağırlığı, bitki başına meyve verimi, dekara verim, meyve kabuğu sertliği, meyve eti sertliği, meyve kabuğu kalınlığı, odacık (karpel) sayısı, meyve başına düşen tohum sayısı, pH, elektriksel iletkenlik (EC), titre edilebilir asit miktarı (TA), suda çözünebilir kuru madde (SÇKM), kuru madde oranı ve tat-aroma, meyve rengi ( $\mathrm{L}, \mathrm{a}, \mathrm{b}, \mathrm{C}, \mathrm{Hue}$ ) parametrelerine bakılmıştır. Araştırma sonucunda, en yüksek verim $5914 \mathrm{~kg} / \mathrm{da}$ ile GULDAR domates genotipinden elde edilirken, en düşük verim değerleri (3197 ve $3313 \mathrm{~kg} / \mathrm{da}$ ) sırasıyla KUZEYKÖY ve LiCE domates genotiplerinden elde edilmiştir. Çeşitler tat-aroma bakımından değerlendirildiğinde, en yüksek tataroma değerine (4.44) GULDAR genotipinin sahip olduğu; en düşük tat-aroma değerine (2.51) ise ASPEM genotipinin sahip olduğu belirlenmiştir.

Anahtar kelimeler: Guldar, Bingöl, domates, verim, kalite

\section{Field and Laboratory Studies for 'Guldar' Tomatoes to Obtain Geographical Indication} \begin{abstract}
Geographical indication is a sign indicating the product integrated with the area, region or country where its origin is located in terms of a distinctive feature, reputation or other features. As with all products, it is very important to carry out studies to obtain geographical indications for agricultural products. This research was carried out in to determine the morphological, physiological, chemical, and yield characteristics of 7 table tomato genotypes in the vegetation period of 2019, with the purpose of the village tomato named "Guldar" in Bingöl to obtain geographical indication. The research was carried out in two different locations, under open field conditions, according to a randomized complete block design with three replications. In comparison of tomato genotypes, germination rate in seeds, first flowering, first fruit set and time to first harvest, chlorophyll content (SPAD), average fruit width, average fruit length, fruit index, stem pit width in fruit, average fruit number, average fruit weight, fruit yield per plant, yield per decare, fruit skin firmness, fruit flesh firmness, fruit skin thickness, carpel number, number of seeds per fruit, $\mathrm{pH}$, electrical conductivity (EC), titratable acid content (TA), total soluble solids (TSS), dry matter ratio and taste-flavor, fruit color ( $L, a, b, C$, Hue) parameters were examined. According to the results, while the highest yield was obtained from GULDAR tomato genotype with $5914 \mathrm{~kg} / \mathrm{da}$, the lowest yield was obtained from KUZEYKÖY and LICE tomato genotypes with 3197 ve $3313 \mathrm{~kg} / \mathrm{da}$, respectively. When the genotypes are evaluated in terms of taste-flavor, GULDAR genotype has the highest taste-flavor value (4.44), while ASPEM genotype has the lowest taste-flavor value (2.51).
\end{abstract}




\section{Giriş}

Coğrafi işaretler, belirli bir yöre, alan, bölge veya ülkeden kaynaklanan bir ürünü tanımlayan, ya da kalitesi, ünü veya diğer karakteristik özellikleri bakımından coğrafi menşeine atfedilen, bir bölgeyi temsil eden sınaî mülkiyet hakkını ifade edilmektedir (Ilıcalı, 2005; Josling, 2005; Şahin ve Meral, 2012). Ülkemizde 10.01.2017 tarih ve 29944 sayılı Resmi Gazetede yayımlanarak yürürlüğe 6769 sayılı Sınai Mülkiyet Kanununun 34 üncü maddesine göre; Coğrafi işaret 'Belirgin bir niteliği, ünü veya diğer özellikleri bakımından kökenin bulunduğu yöre, alan, bölge veya ülke ile özdeşleşmiş ürünü gösteren işarettir' şeklinde tanımlanmıştır. Coğrafi işaret uygulaması özetle yerel bir ürünün veya değerin belli yasalar çerçevesinde kayıt ve koruma altına alınması şeklinde değerlendirilebilir (Şahin, 2013). Tarım, gıda, maden, sanayi ürünleri, el sanatları gibi birçok konu, coğrafi işaret tesciline konu olabilmektedir.

Coğrafi işaretlerin, geleneksel bilgi ve kültür değerlerini korumak, ürün taklitçiliğini önlemek, ülkelerin tanıtımına ve buna bağlı olarak turizme katkıda bulunmak, yerel üretimi desteklemek, çevreyi ve biyolojik çeşitliliği korumak ve ürün kalitesini garanti etmek gibi birçok önemli işlevi vardır (Tepe, 2008). Coğrafi işaretleri önemli kılan en iyi özellik ise yerel ürün ve lezzetlerin bu uygulama ile koruma altına alınabileceği ve bunun yerelde ekonomik aracı olarak kullanılabileceği olgusudur (Güler ve ark., 2016).

Türkiye, sahip olduğu Malatya kayısısı, Antep fıstığı, Maraş biberi, Isparta gülü, Anamur muzu, Aydın inciri, Taşköprü Sarımsağı, Diyarbakır karpuzu, Safranbolu Safranı, Tunceli Sarımsağı, Boyabat Gazidere Domatesi gibi birçok tarımsal ürünleriyle, zengin mutfağıyla, kültür ve sanat zenginlikleriyle, benzersiz doğasıyla, dünyada başka eşi benzeri olmayan bir coğrafi ürün çeşitliliğine sahiptir. Örneklerden de anlaşılacağı üzere, ülkemizde her ilin, her ilçenin hatta her yörenin kendine özel bir ürün veya ürünlerin üretim kaynağı olduğu ve bu ürün ile bütünleştiği görülmektedir. Bu değerlerden bir tanesi de Bingöl ile özdeşleşen 'Guldar' domatesidir. Henüz çeşit özelliğinde olmayan, köy popülasyonu olarak daha çok Bingöl Merkeze bağlı Akdurmuş köyü sınırları içinde yetiştirilen 'Guldar' domatesi farklı lezzeti nedeniyle yörede tüketiciler tarafından tercih edilmektedir. Ülkemizin tüm güzellikleri gibi bu lezzetin de koruma altına alınması tüm Türkiye'ye ve dünyaya tanıtılması gerekmektedir. 2020 yılı itibari ile Türk Patent Enstitüsü'nün verilerine göre ülkemizde 688 adet ürün coğrafi işaret sınıfında tescillenmiştir (Anonim, 2021). Bu sayı yukarıda da bahsedildiği gibi Türkiye gibi çok farklı iklim, coğrafya, biyoçeşitlilik ve kültürel zenginliklere sahip bir ülke için oldukça yetersizdir.

Bu araştırma, Bingöl'de 'Guldar' ismiyle anılan köy domatesinin coğrafi işaret almasına yönelik olarak, 2019 yılı vejetasyon periyodunda, 7 adet sofralık domates genotipinin morfolojik, fizyolojik, kimyasal ve verim özelliklerinin belirlenmesi amacıyla yürütülmüştür.

\section{Materyal ve Metot}

Bu araştırma, 2019 yılında Bingöl Merkeze bağlı Akdurmuş (Guldar) Köyünde, bir örnek çiftçinin arazisinde (Konum: $38^{\circ} 50^{\prime} 34^{\prime \prime} \mathrm{K}$, $40^{\circ} 28^{\prime} 36^{\prime \prime D}$ ) yürütülmüştür. Domates genotipleri köy sınırları içerisinde iki farklı lokasyonda açık tarla koşullarında, tesadüf blokları deneme desenine göre üç tekerrürlü ve her tekerrürde 15 bitki olacak şekilde yetiştirilmiştir. Çalışmada, bitkisel materyal olarak, çeşit veya köy popülasyonu özelliği gösteren 7 adet domates genotipi kullanılmıştır (Çizelge 1).

Çizelge 1. Araştırmada kullanılan domates genotipleri ve erişim kaynakları

\begin{tabular}{cll}
\hline No & Genotip & Menşei \\
\hline 1 & ASPEM & Asgen Tarım \\
2 & BiN101 & Bingöl - Merkez \\
3 & BiN109 & Bingöl - Ilıcalar \\
4 & GULDAR & Bingöl - Akdurmuş (Guldar) \\
5 & KARAÇOR & Elazı̆ - Kovancılar \\
6 & KUZEYKÖY & Nadide Tohum \\
7 & LiCE & Diyarbakır - Lice \\
\hline
\end{tabular}

Denemeye başlamadan önce her iki lokasyonda da arazilerin genelini temsil edecek şekilde 0-30 cm derinlikten alınan toprak örnekleri Tarım ve Orman Bakanlığı, Doğu Anadolu Tarımsal Araştırma Enstitüsü Toprak ve Bitki Besleme Laboratuvarında analiz edilmiş ve bu örneğe ait değerler Çizelge 2'de verilmiştir. Domates genotiplerinden bazıları hazır fide olarak temin edilirken bazıları için de Bingöl Üniversitesi Tarımsal Uygulama ve Araştırma Merkezine ait seralarda fide üretimi gerçekleştirilmiştir. Domates fideleri, 15 Mayıs 2019 tarihinde, 5-6 gerçek yapraklı oldukları dönemde sıra arası $140 \mathrm{~cm}$ ve sıra üzeri $50 \mathrm{~cm}$ olacak şekilde araziye dikilmiştir. Deneme boyunca arazi ve bitkilerde tüm temel bakım işleri Vural ve ark. (2000)'e göre yürütülmüştür. Araştırma süresince gerçekleşmiş olan bazı iklim verileri Çizelge 3'de verilmiştir.

Tekniğine uygun olarak üretilen domates genotiplerinde tohumlarda çimlenme oranı, ilk çiçeklenme, ilk meyve tutumu ve ilk hasada kadar 
geçen süre, klorofil içeriği (SPAD), ortalama meyve eni, ortalama meyve boyu, meyve indeksi (ortalama meyve boylarının meyve enlerine oranlanmasıyla bulunmuştur), meyvede sap çukuru genişliği, ortalama meyve sayısı, ortalama meyve ağırlığı, bitki başına meyve verimi, dekara verim, meyve kabuğu sertliği, meyve eti sertliği, meyve kabuğu kalınlığı, odacık (karpel) sayısı, meyve başına düşen tohum sayısı, pH, elektriksel iletkenlik (EC), titre edilebilir asit miktarı (TA), suda çözünebilir kuru madde (SÇKM), kuru madde oranı ve tat-aroma, meyve rengi ( $L, a, b, C$, Hue) parametreleri belirlenmiştir.

Çizelge 2. Araştırmanın yürütüldüğü arazinin toprak analiz sonuçları

\begin{tabular}{lcc}
\hline Yapılan Analiz & I. Lokasyon & II. Lokasyon \\
\hline Saturasyon, \% & 53 & 54 \\
$\mathrm{pH}$ & 6.80 & 6.67 \\
Elektriksel Illetkenlik (EC), dS/m & 1.65 & 1.79 \\
Tuz, \% & 0.06 & 0.06 \\
Organik Madde, \% & 3.54 & 2.78 \\
Kireç (CaCO3), \% & 0.16 & 0.16 \\
Potasyum (K2O), kg/da & 88 & 88 \\
Fosfor (P2O5), kg/da & 11.3 & 13.2 \\
Kil, \% & 34.16 & 36.16 \\
Silt, \% & 31.28 & 27.28 \\
Kum, \% & 34.56 & 36.56 \\
Bünye Sınıfı & $\mathrm{CL}$ (Killi Tın) & $\mathrm{CL}$ (Killi Tın) \\
\hline
\end{tabular}

Çizelge 3. Araştırma süresince gerçekleşmiş olan iklim verileri (2019)

\begin{tabular}{lccccccc}
\hline ikim Parametreleri & Mart & Nisan & Mayıs & Haziran & Temmuz & Ağustos & Eylül \\
\hline Ortalama maksimum sıcaklık $\left({ }^{\circ} \mathrm{C}\right)$ & 8.3 & 12.8 & 23.5 & 30.0 & 31.7 & 33.1 & 22.8 \\
Ortalama minimum sıcaklık $\left({ }^{\circ} \mathrm{C}\right)$ & 1.0 & 4.1 & 10.0 & 16.1 & 17.7 & 18.9 & 12.3 \\
Ortalama sıcaklık $\left({ }^{\circ} \mathrm{C}\right)$ & 4.0 & 8.3 & 17.3 & 23.6 & 25.2 & 26.1 & 20.6 \\
Aylık ortalama nispi nem $(\%)$ & 68.0 & 70.0 & 49.3 & 37.8 & 31.8 & 30.5 & 34.3 \\
Aylık toplam yağış $(\mathrm{mm})$ & 121.7 & 183.0 & 75.5 & 3.6 & 0.5 & 44.6 & - \\
\hline
\end{tabular}

Çimlenme testi tesadüf parselleri deneme planına göre laboratuvar koşullarında nem sıcaklık ve ışık kontrollü iklim dolabında (Memmert) 3 tekerrürlü olarak yürütülmüştür. Çimlendirme testi için domates tohumları, içerisinde iki kat kurutma kâğıdı yerleştirilmiş petri kapları içerisine 100'er adet konulmuştur. Her bir petri kabına $5 \mathrm{ml}$ su ilave edilerek tohumlar karanlıkta $25{ }^{\circ} \mathrm{C}^{\prime}$ de çimlenme testine tabi tutulmuşlardır. Çimlendirme süresi boyunca her gün çimlenen tohumlar sayılarak not edilmiş ve petri kaplarından uzaklaştırılmıştır. Çimlenmeye esas olarak kökçük ucunun çıplak gözle görülebilmesi veya kökçüğün $2 \mathrm{~mm}$ büyüklüğünde olması yeterli kabul edilmiştir. Çimlendirme ortamının ihtiyacına göre zaman zaman su ilavesi yapılmıştır.

Meyve ölçümleri her genotip ve tekerrürden alınan rastgele seçilen ve pazarlanabilir özellikle olan 10 meyve üzerinde yapılmıştır. Meyve kabuğu ve meyve eti sertlikleri tesadüfi seçilen meyvelerin ekvatoral bölgesinden iki farklı noktasından 6 mm'lik silindir uç kullanılarak ölçülmüş ve değerler $\mathrm{kg} / \mathrm{cm}^{2}$ olarak verilmiştir. Titre edilebilir asit miktarı ölçümleri Cemeroğlu (2010)'a göre yapılmış ve sitrik asit cinsinden hesaplanmıştır. Tat-aroma görünüm değerlendirmeleri, analiz dönemlerinde tesadüfi olarak seçilen meyvelerde 25 panelist tarafından 15 (1: En kötü; 5: En iyi) arasında puanlar gerçekleştirilmiştir. (Anonymous, 2011). Klorofil içeriği (SPAD) ölçümleri çiçeklenme döneminde tesadüfi olarak belirlenen bitki ve tam gelişmiş yapraklar üzerinde bir portatif klorofilmetre (Minolta SPAD-502, Osaka, Japan) kullanılarak yapılmıştır.

Meyve rengini belirlemek için meyvenin ekvator bölgesinden kromametre ile üç ayrı ölçüm yapılmıştır. Domates meyvelerinde renk; L, $a, b$, Chroma ve Hue değerleri cinsinden değerlendirilmiştir. Kromametrede $L$ değeri parlaklığı, a değeri kırmızıdan yeşile, b değeri ise sarıdan maviye renk değişimlerini ifade etmektedir (López Camelo ve Gómez, 2004).

Araştırmadan elde edilen veriler, 'SAS V9.1' bilgisayar paket programı kullanılarak analiz 
edilmiştir. Domates genotiplerinin incelenen parametreler bakımından, lokasyona göre anlamlı farklılık gösterip göstermediğini belirlemeden önce, Levene's testi ile iki lokasyonun varyanslarının homojenliği test edilmiş, sonuçta varyanslarının homojen olduğu görülmüştür. Bu nedenle iki lokasyondan elde edilen değerlerin ortalaması alınmış daha sonra ortalamalar arasındaki farkın belirlenmesi işlemlerine geçilmiştir. Önemli farklılıklarda grup ortalamaların karşılaştırılmasında Duncan Çoklu Karşılaştırma Testi (DMCT) kullanılmıştır.

\section{Bulgular ve Tartışma}

Tohumlarda çimlenme oranı, ilk çiçeklenmeye kadar geçen süre, ilk meyve hasadına kadar geçen süre, Klorofil içeriği (SPAD)

Çalışmadan elde edilen bulgulara göre, çimlenme oranı değerleri dikkate alındığında domates genotipleri arasındaki fark istatistiki anlamda önemli $(P \leq 0,05)$ bulunmuştur. Domates genotiplerinde tohum çimlenme oranları \%88.33 ile \%98.00 arasında değişmiştir. LiCE domates tohumları (\%88.33) ile en düşük çimlenme oranını verirken, GULDAR domates tohumları (\%98.00) ile en yüksek çimlenme oranı elde edilmiştir. Bunu istatistiksel olarak aynı grupta diğer domates genotipleri takip etmiştir (Çizelge 4). Fide dikiminden ilk çiçeklenmeye kadar geçen süreler ile ilgili bulgular incelendiğinde bu sürenin 12 ile 30 gün arasında değiştiği; en kısa sürenin 12 gün ile LiCE domatesinden, en uzun sürenin ise 30 gün ile KUZEYKÖY domatesinden elde edildiği görülmektedir (Çizelge 4). Dikimden ilk meyve tutumuna kadar geçen süreler ile ilgili bulgular incelendiğinde bu sürenin 18.00 ile 37.66 gün arasında değiştiği; en kısa sürenin 18,00 gün ile LiCE domatesinden, en uzun sürenin ise 37,66 gün ile KUZEYKÖY domatesinden elde edildiği görülmektedir (Çizelge 4). Fide dikiminden hasada kadar geçen süre açısından ele alındığında; bu sürenin domates genotiplerine göre değişiklik gösterdiği; en kısa sürenin 57,00 gün ile LiCE domatesinden, en uzun sürenin ise 81.33 gün KUZEYKÖY domatesinden elde edilmiştir (Çizelge 4). Domates genotiplerinde klorofil içeriği (SPAD) bakımından istatistiksel olarak önemli $(p<0.01)$ farklılıklar bulunmuştur. Çizelge 4 incelendiğinde genotiplerinin klorofil içeriklerinin 46.72 ile 58.17 arasında değişim gösterdiği; en yüksek klorofil içeriğinin 58.17 ile GULDAR domatesinden, en düşük klorofil içeriğinin ise 46.72 ile BiN109 domatesinden elde edildiği görülmektedir.

Çizelge 4. Denemeye alınan domates genotiplerine ait tohum çimlenme oranı, dikimden ilk çiçeklenmeye kadar süre, dikimden ilk meyve tutumuna kadar geçen süre ve dikimden ilk hasada kadar geçen süre ve göreceli klorofil içeriği (SPAD) değerleri.

\begin{tabular}{cccccc}
\hline Genotipler & $\begin{array}{c}\text { Tohumlarda } \\
\text { Çimlenme Oranı } \\
(\%)^{y}\end{array}$ & $\begin{array}{c}\text { Illk Çiçeklenmeye } \\
\text { Kadar Süre (gün) }\end{array}$ & $\begin{array}{c}\text { İlk Meyve Tutumuna } \\
\text { Kadar Geçen Süre } \\
\text { (gün) }\end{array}$ & $\begin{array}{c}\text { ilk Hasada } \\
\text { Kadar Geçen } \\
\text { Süre (gün) }\end{array}$ & $\begin{array}{c}\text { Klorofil } \\
\text { İçeriği (SPAD) }\end{array}$ \\
\hline ASPEM & $94.00 \mathrm{ab}$ & $21.00 \mathrm{~b}$ & $29.00 \mathrm{c}$ & $77.66 \mathrm{bc}$ & $51.44 \mathrm{bc}$ \\
BiN101 & $94.00 \mathrm{ab}$ & $16.00 \mathrm{c}$ & $23.00 \mathrm{~d}$ & $72.00 \mathrm{~d}$ & $48.55 \mathrm{~cd}$ \\
BiN109 & $96.66 \mathrm{a}$ & $16.00 \mathrm{c}$ & $25.00 \mathrm{~d}$ & $73.00 \mathrm{~d}$ & $46.72 \mathrm{~d}$ \\
GULDAR & $98.00 \mathrm{a}$ & $15.00 \mathrm{c}$ & $25.00 \mathrm{~d}$ & $75.00 \mathrm{~cd}$ & $58.17 \mathrm{a}$ \\
KARAÇOR & $97.33 \mathrm{a}$ & $22.00 \mathrm{~b}$ & $33.66 \mathrm{~b}$ & $78.33 \mathrm{ab}$ & $48.55 \mathrm{~cd}$ \\
KUZEYKÖY & $93.33 \mathrm{ab}$ & $30.00 \mathrm{a}$ & $37.66 \mathrm{a}$ & $81.33 \mathrm{a}$ & $52.94 \mathrm{~b}$ \\
LiCE & $88.33 \mathrm{~b}$ & $12.00 \mathrm{~d}$ & $18.00 \mathrm{e}$ & $57.00 \mathrm{e}$ & $51.11 \mathrm{bc}$ \\
\hline Önemlilik & $*$ & $* *$ & $* *$ & $* *$ & $* *$ \\
\hline
\end{tabular}

${ }^{y}$ Aynı sütunda farklı harflerle gösterilen ortalamalar arasındaki fark önemlidir.

${ }^{*} \mathrm{p}<0.05$ düzeyinde önemli, ${ }^{* *} \mathrm{p}<0.01$ düzeyinde önemli

\section{Meye boyu, Meyve eni, Meyve indeksi, Sap çukuru genişliği}

Çalışma sonucunda, meyve boyu yönünden genotipler arasında istatistiksel olarak önemli $(p<0.05)$ bir farklılık bulunamamıştır (Çizelge 5). Meyve boyu değerleri 50.15-61.68 mm mm arasında değişmiştir. Araştırmaya konu olan domateslerde meyve eni yaklaşık $59.46 \mathrm{~mm}$ ile $84.93 \mathrm{~mm}$ arasında değişmiş olup, meyve eni yönünden genotipler arasındaki fark istatistiksel olarak önemli $(p<0.01)$ bulunmuştur (Çizelge 5$)$. En yüksek meyve eni değerleri sırasıyla BíN109 (83.99 $\mathrm{mm}$ ) ve GULDAR $(84.93 \mathrm{~mm}$ ) genotiplerinden elde edilmiştir. Diğer taraftan en düşük meyve eni değeri ise 59.46 mm ile LiCE genotipinden elde edilmiştir. Domates genotiplerinin meyve indeksi üzerindeki etkisi istatistikî olarak $(p<0.05)$ önemli bulunmuştur (Çizelge 5). En yüksek meyve indeks değerleri KUZEYKÖY ve LICE genotiplerinden elde edilirken, en düşük meyve indeks değeri (0.71) ise ASPEN genotipinden elde edilmiştir (Çizelge 5). Özbay ve ark. (2012) tarafından tarla koşullarında yürütülen 
domates çeşit denemesinde meyve indeksi 0.631.39 arasında değişmiştir. Genotiplerin sap çukuru genişliği değerleri incelendiğinde, aralarındaki farkın istatistikî olarak önemli $(p<0.01)$ olduğu saptanmıştır (Çizelge 5). Araştırmaya konu olan domateslerde sap çukuru genişlikleri $11.92 \mathrm{~mm}$ ile $14.35 \mathrm{~mm}$ arasında değişmiştir.

Çizelge 5. Denemeye alınan domates genotiplerine ait meyve boyu, meyve eni, meyve indeksi ve sap çukuru genişliği değerleri.

\begin{tabular}{lcccc}
\hline Genotipler & $\begin{array}{c}\text { Meyve Boyu } \\
(\mathrm{mm})\end{array}$ & $\begin{array}{c}\text { Meyve Eni } \\
(\mathrm{mm})\end{array}$ & Meyve Indeksi & $\begin{array}{c}\text { Sap Çukuru } \\
\text { Genişliği }(\mathrm{mm})\end{array}$ \\
\hline ASPEM & 50.97 & $71.58 \mathrm{bc}$ & $0.71 \mathrm{bc}$ & $14.35 \mathrm{a}$ \\
BIN101 & 51.26 & $75.62 \mathrm{~b}$ & $0.68 \mathrm{c}$ & $13.60 \mathrm{ab}$ \\
BiN109 & 55.57 & $83.99 \mathrm{a}$ & $0.66 \mathrm{c}$ & $14.18 \mathrm{a}$ \\
GULDAR & 58.05 & $84.93 \mathrm{a}$ & $0.68 \mathrm{c}$ & $13.69 \mathrm{ab}$ \\
KARAÇOR & 49.82 & $67.75 \mathrm{c}$ & $0.74 \mathrm{bc}$ & $12.39 \mathrm{bc}$ \\
KUZEYÖY & 61.68 & $69.62 \mathrm{c}$ & $0.88 \mathrm{a}$ & $12.44 \mathrm{bc}$ \\
LiCE & 50.11 & $59.46 \mathrm{~d}$ & $0.84 \mathrm{ab}$ & $11.92 \mathrm{c}$ \\
\hline Önemlilik & ö.d. & $* *$ & $*$ & $* *$
\end{tabular}

Önemlilik ö.d.

ö.d. Önemli değil, ${ }^{*}$ p $<0.05$ düzeyinde önemli, ${ }^{* *} p<0.01$ düzeyinde önemli,

Ortalama meyve sayısı, Ortalama meyve ağırlığı, Bitki başına verim, Dekara verim değerleri

Domates genotiplerinin bitki başına düşen meyve sayısı üzerindeki etkisi istatistikî olarak $(p<0.01)$ önemli bulunmuştur (Çizelge 6). Domateste verimi belirlemede kullanılan önemli parametrelerden birisi olan bitki başına ortalama meyve sayısı 13.50-17.50 adet arasında değişmiştir. En düşük bitki başına meyve sayısı 13.50 adet ile KARAÇOR genotipinden alınırken, en fazla meyve sayısı ise 17.50 adet ile LiCE genotipinden alınmıştır. LiCE domatesini aynı grupta yer alan GULDAR ve KUZEYKÖY domates genotipleri takip etmiştir. Genotipler ortalama meyve ağırlığı bakımından incelendiğinde, aralarındaki farkın istatistikî olarak önemli $(p<0.01)$ olduğu ortaya çıkmıştır (Çizelge 6). Ortalama meyve ağırlığı değerleri 140.10 ile 293.71 g arasında değişmiştir. En yüksek ortalama meyve ağırlığı değeri (293.71 g) GULDAR genotipinden elde edilirken, en düşük ortalama meyve ağırlığı değeri (140.10 g) ise LiCE domatesinden elde edilmiştir (Çizelge 6). Ortalama meyve ağırlığı ile ilgili sonuçlar bu araştırmada yer alan genotiplerimizin bazıları ile daha önce yürütülen çalışmalarla uyum içerisinde değildir. Özbay ve Ateş (2015) tarafından Bingöl merkezde çeşit adaptasyon araştırmasında GULDAR domatesi bizim sonuçlarımıza göre daha düşük ortalama meyve ağırlığı değerine sahip olmuştur. Bizim sonuçlarımızın farklı çıkması söz konusu araştırmanın yürütüldüğü ekolojinin farklı olmasından kaynaklanmış olabilir. Diğer taraftan ortalama meyve ağırığı bakımından genotipler arasında istatistiksel olarak fark çıkması çeşitler arasındaki genotipsel farklılıktan kaynaklanmış olablir.

Çizelge 6. Denemeye alınan domates genotiplerine ait ortalama meyve sayısı, ortalama meyve ağırlığı, bitki başına verim ve dekara verim değerleri.

\begin{tabular}{lcccc}
\hline Genotipler & $\begin{array}{c}\text { Meyve Sayısı } \\
\text { (adet/bitki) }\end{array}$ & $\begin{array}{c}\text { Meyve } \\
\text { Ağılığı }(\mathrm{g})\end{array}$ & $\begin{array}{c}\text { Bitki Verimi } \\
(\mathrm{kg} / \mathrm{bitki})\end{array}$ & $\begin{array}{c}\text { Dekara Verim } \\
(\mathrm{kg} / \mathrm{da})\end{array}$ \\
\hline ASPEM & $14.50 \mathrm{~cd}$ & $207.10 \mathrm{~cd}$ & $2.85 \mathrm{~d}$ & $3993 \mathrm{c}$ \\
BIN101 & $14.83 \mathrm{bcd}$ & $234.90 \mathrm{bc}$ & $3.31 \mathrm{c}$ & $4619 \mathrm{~b}$ \\
BIN109 & $14.00 \mathrm{~cd}$ & $265.67 \mathrm{ab}$ & $3.51 \mathrm{~b}$ & $4842 \mathrm{~b}$ \\
GULDAR & $16.67 \mathrm{ab}$ & $293.71 \mathrm{a}$ & $4.47 \mathrm{a}$ & $5914 \mathrm{a}$ \\
KARAÇOR & $13.50 \mathrm{~d}$ & $191.85 \mathrm{~d}$ & $2.54 \mathrm{ef}$ & $3407 \mathrm{~d}$ \\
KUZEYKÖY & $15.83 \mathrm{abc}$ & $174.52 \mathrm{de}$ & $2.61 \mathrm{e}$ & $3167 \mathrm{e}$ \\
LiCE & $17.50 \mathrm{a}$ & $140.10 \mathrm{e}$ & $2.48 \mathrm{f}$ & $3313 \mathrm{e}$ \\
\hline Önemlilik & $* *$ & $* *$ & $* *$ & $* *$
\end{tabular}

${ }^{y}$ Aynı sütunda farklı harflerle gösterilen ortalamalar arasındaki fark önemlidir

** $\mathrm{p}<0.01$ düzeyinde önemli

Araştırmada denemeye alınan domates genotiplerinde bitki başına verim 2.48 ile $4.47 \mathrm{~kg}$ arasında değişmiştir (Çizelge 6). GULDAR genotipi
$4.47 \mathrm{~kg} / \mathrm{bitki}$ değeri ile en yüksek bitki başına verim değerine sahip olurken; LiCE domates ise 2.48 $\mathrm{kg} /$ bitki değeri ile en düşük bitki başına verim 
değerine sahip olmuştur (Çizelge 6). Domateste verim; çeşit, ekoloji ve bakım şartlarına bağlıdır. Tarla koşullarında, iyi bir çeşit ve uygun şartlarda yapılan domates üretiminde meyve iriliklerine göre bitki başına 2-12 kg arasında verim alınabilmektedir (Eşiyok ve ark., 2004). Domates genotiplerinin dekara verim üzerindeki etkisi istatistikî olarak önemli $(p<0.01$ ) bulunmuştur (Çizelge 6$)$. En yüksek dekara verim değeri (5914 kg) GULDAR genotipinden elde edilirken, en düşük dekara verim değerleri (3197 ve 3313 kg) sırasıyla KUZEYKÖY ve LiCE domates genotiplerinden elde edilmiştir (Çizelge 6). Domates çeşitleri veya genotiplerinden alınan verim değerleri farklı lokasyon ve iklim koşullarına bağı olarak değişkenlik gösterebilmektedir. Örneğin bizim çalışmamızda GULDAR domates genotipi dekara 5914 kg verim verirken, Bingöl merkezde Özbay ve Ateş (2015) tarafından yürütülen çeşit adaptasyon denemelerinde GULDAR domatesi 5289 kg verim vermiştir. Bizim sonuçlarımızın farklı çıkması araştırmanın yürütüldüğü ekolojinin söz konusu domates genotipinin yoğunlukla yetiştirildiği Bingöl Merkeze bağlı Akdurmuş mahallesinin ekolojisinden farklı olmasından kaynaklanmış olabilir.

\section{Meyve kabuğu sertliği, Meyve eti sertliği, Meyve kabuğu kalınlığı, Odacık (Karpel) sayısı, Tohum sayısı}

Domates genotiplerinin meyve kabuğu sertliği üzerindeki etkisi istatistikî olarak önemli $(p<0.01)$ bulunmuştur (Çizelge 7). En yüksek meyve kabuğu sertliği değeri $\left(2.86 \mathrm{~kg} / \mathrm{cm}^{2}\right)$ GULDAR genotipinden elde edilirken, en düşük meyve kabuğu sertliği değeri $\left(2.86 \mathrm{~kg} / \mathrm{cm}^{2}\right) \quad$ LiCE domatesinden elde edilmiştir. Domates genotiplerinin meyve eti sertliği değerleri arasındaki fark istatistik olarak önemli $(p<0.01)$ bulunmuştur (Çizelge 7). En yüksek meyve eti sertliği değerleri (1.64 ve $1.66 \mathrm{~kg} / \mathrm{cm}^{2}$ ) sırasıyla LiCE ve GULDAR genotiplerinden elde edilirken, en düşük meyve kabuğu sertliği değeri $\left(1.15 \mathrm{~kg} / \mathrm{cm}^{2}\right)$ KUZEYKÖY genotipinden elde edilmiştir. Incelenen domates genotiplerinde meyve kabuğu kalınlığının çeşitlere göre değişimi istatistiksel açıdan önemli $(p<0.01)$ bulunmuştur (Çizelge 7). Genotiplere göre en yüksek meyve kabuğu kalınlığı değerine sahip olan çeşidin ASPEM olduğu belirlenmiştir. En düşük meyve kabuğu kalınlığı değeri ise LiCE genotipinde saptanmıştır. Yapılan çalışmada genotiplerin meyvede odacık (karpel) sayısı arasındaki farklılıklar önemli ( $p<0.01$ ) bulunmuştur (Çizelge 7$)$. Domates meyvelerinde odacık (karpel) sayısı değerleri 6.05 ile 7.90 adet arasında değişmiştir. Domates genotiplerinde meyve başına tohum sayısının çeşitlere göre değişimi istatistiksel açıdan önemli $(p<0.01)$ bulunmuştur (Çizelge 7). Domateslerde meyve başına tohum sayısı genellikle 150 - 250 tohum arasında değişir (McCormack, 2004). Bizim çalışmamızda da denemeye alınan genotiplerde meyve başına tohum sayısının 120 - 214 adet arasında değiştiği saptanmıştır.

Çizelge 7. Denemeye alınan domates genotiplerine ait meyve kabuğu sertliği, meyve eti sertliği, meyve kabuğu kalınlığı, odacık (karpel) sayısı ve meyve başına düşen tohum sayısı.

\begin{tabular}{lccccc}
\hline Genotipler & $\begin{array}{c}\text { Meyve Kabuğu } \\
\text { Sertliği } \\
\left(\mathrm{kg} / \mathrm{cm}^{2}\right)^{y}\end{array}$ & $\begin{array}{c}\text { Meyve Eti } \\
\text { Sertliği } \\
\left(\mathrm{kg} / \mathrm{cm}^{2}\right)\end{array}$ & $\begin{array}{c}\text { Meyve } \\
\text { Kabuğu } \\
\text { Kalınlığ }(\mathrm{mm})\end{array}$ & $\begin{array}{c}\text { Odacık } \\
\text { Sayısı (adet) }\end{array}$ & $\begin{array}{c}\text { Tohum } \\
\text { Sayısı } \\
\text { (adet/meyve) }\end{array}$ \\
\hline ASPEM & $2.38 \mathrm{~b}$ & $1.42 \mathrm{abc}$ & $0.41 \mathrm{a}$ & $7.02 \mathrm{bc}$ & $162 \mathrm{~b}$ \\
BIN101 & $2.37 \mathrm{~b}$ & $1.18 \mathrm{c}$ & $0.28 \mathrm{bc}$ & $7.57 \mathrm{abc}$ & $214 \mathrm{a}$ \\
BiN109 & $2.20 \mathrm{bc}$ & $1.40 \mathrm{abc}$ & $0.31 \mathrm{abc}$ & $7.90 \mathrm{a}$ & $167 \mathrm{~b}$ \\
GULDAR & $2.86 \mathrm{a}$ & $1.64 \mathrm{ab}$ & $0.32 \mathrm{abc}$ & $7.67 \mathrm{ab}$ & $172 \mathrm{~b}$ \\
KARAÇOR & $2.27 \mathrm{bc}$ & $1.27 \mathrm{bc}$ & $0.34 \mathrm{ab}$ & $5.64 \mathrm{~d}$ & $130 \mathrm{c}$ \\
KUZEKÖY & $2.14 \mathrm{bc}$ & $1.15 \mathrm{c}$ & $0.32 \mathrm{abc}$ & $6.95 \mathrm{c}$ & $120 \mathrm{c}$ \\
LiCE & $2.02 \mathrm{c}$ & $1.66 \mathrm{a}$ & $0.23 \mathrm{c}$ & $6.05 \mathrm{~d}$ & $147 \mathrm{bc}$ \\
\hline Önemlilik & $* *$ & $* *$ & $* *$ & $* *$ & $* *$
\end{tabular}

${ }^{y}$ Aynı sütunda farklı harflerle gösterilen ortalamalar arasındaki fark önemlidir

** $\mathrm{p}<0.01$ düzeyinde önemli,

\section{pH, elektriksel iletkenlik (EC), Titre edilebilir asit miktarı (TA), Suda çözünür kuru madde miktarı (SÇKM), Kuru madde oranı, Tat-aroma}

Domateste $\mathrm{pH}$ değerleri çeşide bağlı olarak farklılık gösterebilir. Denemeye alınan genotiplerde pH değerleri 3.43-4.08 arasında değişmiştir. Genotiplerin $\mathrm{pH}$ değerleri arasındaki farklılıklar önemli $(p<0.01$ ) bulunmuştur (Çizelge 8 ). Domates genotipleri arasında GULDAR en yüksek pH değerine
(4.08) sahip olurken; BiN109 genotipi ise en düşük $\mathrm{pH}$ değerine (3.43) sahip olmuştur. Araştırmamızdan elde edilen $\mathrm{pH}$ sonuçları daha önceki çalışmalarla (Baykal ve ark., 1983; Kaya, 2012) benzerlik göstermektedir. Çalışma sonucunda, elektriksel iletkenlik (EC) ve titre edilebilir asit miktarı (TA) yönünden genotipler arasında istatistiksel olarak önemli $(p<0.05)$ bir farklılık bulunamamıştır (Çizelge 8). Araştırmaya 
konu olan genotiplerde suda çözünür kuru madde miktarı değerleri \%4.97-5.93 arasında değişmiştir. Genotiplerin SÇKM değerleri arasındaki farklılıklar önemli $(p<0.01)$ bulunmuştur (Çizelge 8$)$. Suda çözünebilir kuru madde miktarı \%5.93 ile en yüksek GULDAR domatesinde belirlenmiştir. Bu çeşidi \%5.67 ile BiN109 genotipi izlemiştir. Araştırmamızdan elde edilen SÇKM sonuçları Sağlam ve Taşova (2017) tarafından Tokat koşullarında yürütülen çeşit adaptasyon çalışmasında elde edilen SÇKM sonuçları ile paralellik göstermektedir. Sağlam ve Taşova (2017), 39 domates çeşidiyle yaptıkları çalışmada, SÇKM miktarlarının \%4.23-5.87 olarak belirlemişlerdir. Araştırma sonucunda, kuru madde oranı yönünden genotipleri arasında istatistiksel olarak önemli $(p<0.05)$ bir farklılık bulunamamıştır (Çizelge 8). Domates genotiplerinin tat-aroma değerleri arasındaki farklar $(p<0.01)$ seviyesinde önemli bulunmuştur (Çizelge 8). Genotipler tat-aroma bakımından değerlendirildiğinde, en yüksek tataroma değerine (4.44) GULDAR genotipinin sahip olduğu; en düşük tat-aroma değerine (2.51) ise ASPEM genotipinin sahip olduğu ortaya çıkmıştır.

Çizelge 8. Denemeye alınan domates genotiplerine ait $\mathrm{pH}$, elektriksel iletkenlik (EC), titre edilebilir asit miktarı (TA), suda çözünür kuru madde miktarı (SÇKM), kuru madde oranı ve tat-aroma değerleri.

\begin{tabular}{lcccccc}
\hline Genotipler & $\mathrm{pH}^{\mathrm{y}}$ & $\mathrm{EC}$ & $\mathrm{TA}(\%)$ & $\begin{array}{c}\text { SÇKM } \\
(\%)\end{array}$ & Kuru Madde Oranı (\%) & $\begin{array}{c}\text { Tat -Aroma } \\
(1-5)^{\mathrm{z}}\end{array}$ \\
\hline ASPEM & $3.57 \mathrm{bc}$ & 5.23 & 0.41 & $5.45 \mathrm{~b}$ & 9.21 & $2.51 \mathrm{e}$ \\
BIN101 & $3.58 \mathrm{bc}$ & 5.2 & 0.42 & $5.55 \mathrm{~b}$ & 8.83 & $3.42 \mathrm{c}$ \\
BIN109 & $3.43 \mathrm{c}$ & 4.90 & 0.37 & $5.67 \mathrm{ab}$ & 9.63 & $3.90 \mathrm{~b}$ \\
GULDAR & $4.08 \mathrm{a}$ & 4.70 & 0.38 & $5.93 \mathrm{a}$ & 8.70 & $4.44 \mathrm{a}$ \\
KARAÇOR & $3.78 \mathrm{abc}$ & 4.70 & 0.41 & $4.54 \mathrm{~d}$ & 8.88 & $2.68 \mathrm{de}$ \\
KUZEYKÖY & $3.50 \mathrm{c}$ & 4.86 & 0.40 & $4.59 \mathrm{~d}$ & 9.10 & $2.93 \mathrm{~d}$ \\
LiCE & $3.95 \mathrm{ab}$ & 5.13 & 0.39 & $4.97 \mathrm{c}$ & 10.12 & $2.93 \mathrm{~d}$ \\
\hline Önemlilik & $* *$ & ö.d. & ö.d. & $* *$ & o.d. & $* *$ \\
\hline
\end{tabular}

${ }^{y}$ Aynı sütunda farklı harflerle gösterilen ortalamalar arasındaki fark önemlidir

${ }^{* *} p<0.01$ düzeyinde önemli, ${ }^{* * *} p<0.001$ düzeyinde önemli, ${ }^{2} 1-5$ (1: En kötü; 5: En iyi)

Meyve rengi: Parlaklık (L), A Değeri, B Değeri, Chroma Değeri Hue Değeri

Domates genotiplerinin meyvelerinin renk karakteristiklerine ait değerler Çizelge 9'a verilmiştir. L (parlaklık), a (kırmızı-yeşil), b (sarımavi), Chroma ve Hue (renk tonu) ölçüm değerleri dikkate alındığında domates genotipleri arasındaki fark istatistiki anlamda önemli bulunmuştur (Çizelge 9). Domates meyvelerine ait en yüksek parlaklık (L) değeri 41,29, en düşük parlaklık değeri ise, 27,54 olarak belirlenmiştir. Kırmızı (a) ve sarılık (b) değerleri ise en küçük ve en büyük ve olmak üzere sırasıyla; $18,02-26,81$ ve $12,89-29,57$ olarak belirlenmiştir. Chroma ve Hue renk değerleri ise en küçük ve en büyük ve olmak üzere sırasıyla; 22,9436,28 ve 33,69-53,45 olarak bulunmuştur. Renk değerleri ile ilgili olarak elde edilen bulgular López Camelo ve Gómez (2004) ile uyum içerisindendir. Domateste meyve kalitesi hakkında ilk yargı genellikle ürün rengine bakılarak verilir. Meyvelerin özellikle $a^{*}$ kırmızılık değerlerinde pozitif ' + ' değerler vermesi genotiplerin meyve renginin kırmızı renkli olduğunu göstermektedir. Chroma (C) değeri, burada domates meyvelerinde meyve kabuğunun canlılığını-donukluğunu ifade etmektedir. Canlı renklerde chroma değerleri yüksek iken donuk renklerde ise kroma değeri düşük olmaktadır.

Çizelge 9. Denemeye alınan domates genotipleri meyvelerine ait renk değerleri

\begin{tabular}{lccccc}
\hline Genotipler & Parlaklık $(\mathrm{L})^{\mathrm{y}}$ & A Değeri & B Değeri & Chroma Değeri & Hue Değeri \\
\hline ASPEM & $+36.91 \mathrm{ab}$ & $+18.02 \mathrm{~b}$ & $+12.89 \mathrm{~b}$ & $+22.94 \mathrm{~b}$ & $+33.69 \mathrm{~b}$ \\
BiN101 & $+34.93 \mathrm{ab}$ & $+23.35 \mathrm{ab}$ & $+27.33 \mathrm{a}$ & $+36.28 \mathrm{a}$ & $+49.73 \mathrm{a}$ \\
BiN109 & $+36.28 \mathrm{ab}$ & $+23.37 \mathrm{ab}$ & $+25.05 \mathrm{a}$ & $+34.31 \mathrm{a}$ & $+47.01 \mathrm{a}$ \\
GULDAR & $+41.29 \mathrm{a}$ & $+26.81 \mathrm{a}$ & $+27.01 \mathrm{a}$ & $+36.08 \mathrm{a}$ & $+49.07 \mathrm{a}$ \\
KARAÇOR & $+29.76 \mathrm{~b}$ & $+22.61 \mathrm{ab}$ & $+29.57 \mathrm{a}$ & $+37.37 \mathrm{a}$ & $+52.45 \mathrm{a}$ \\
KUZEYKÖY & $+27.54 \mathrm{~b}$ & $+23.97 \mathrm{ab}$ & $+23.87 \mathrm{a}$ & $+33.89 \mathrm{a}$ & $+44.11 \mathrm{a}$ \\
LiCE & $+35.23 \mathrm{ab}$ & $+23.29 \mathrm{ab}$ & $+29.20 \mathrm{a}$ & $+30.17 \mathrm{ab}$ & $+51.16 \mathrm{a}$ \\
\hline Önemlilik & $*$ & $* *$ & $* *$ & $* *$ & $* *$
\end{tabular}

${ }^{y}$ Aynı sütunda farklı harflerle gösterilen ortalamalar arasındaki fark önemlidir

* $\mathrm{p}<0.05$ düzeyinde önemli, ${ }^{* *} \mathrm{p}<0.01$ düzeyinde önemli, 


\section{Sonuç ve Öneriler}

Ülkemizde her ilin, her ilçenin hatta her yörenin kendine özel bir ürün veya ürünlerin üretim kaynağı olduğu ve bu ürün ile bütünleştiği görülmektedir. Bu değerlerden bir tanesi de Bingöl ile özdeşleşen 'Guldar' domatesidir. Ülkemizin tüm güzellikleri gibi bu lezzetin de koruma altına alınması ve coğrafi işaret alarak tüm Türkiye'ye ve dünyaya tanıtılması oldukça önemlidir. Buradan hareketle, yürütülen bu araştırmada, içinde 'Guldar' domatesinin de bulunduğu 7 adet sofralık domates genotipinin morfolojik, fizyolojik, kimyasal ve verim özellikleri belirlenmiştir. Çeşit denemelerinde en önemli parametre olan verim ve verim komponentleri dikkate alındığında, GULDAR genotipi diğer çeşitlere oranla daha yüksek verim vermiştir. Bunun yanında araştırma soncunda tataroma bakımından da GULDAR genotipinin daha iyi sonuçlar verdiği ortaya çıkmıştır. İri köy domatesi veya yerli domates olarak adlandırılan domates çeşitlerinde en büyük sıkıntı bu domateslerin raf ömrünün az olması ve nakliyeye dayanıklı olmamalarıdır. Nakliye dayanıklı çeşitlerin hem meyve kabuğu hem me meyve eti sertliğinin iyi olması beklenir. Bu açıdan değerlendirildiğinde, meyve eti sertliğinin denenen diğer çeşitlere göre yüksek olması nedeniyle GULDAR domatesi ön plana çıkmaktadır. Araştırmada elde edilen bulgular ışığında, 'Guldar' domatesinin kendi ekolojisinde yetiştirildiğinde kendine has lezzet ve aromayı daha iyi yansıttığı ve daha iyi verim verdiği söylenilebilir.

Teşekkür: Bu çalışmaya destek veren Bingöl Tarım ve Orman İ Müdürlüğü yöneticilerine, çalışanlarına, özellikle Ahmet BOZABA'ya ve Akdurmuş Köyü Muhtarı Mahmut BAHADIR'a teşekkür ederim.

Çıkar Çatışması Beyanı: Makale yazarı herhangi bir çıkar çatışması olmadığını beyan ederler.

\section{Kaynaklar}

Anonim, 2021. Coğrafi işaret tescil ve başvuru sayıları. Türkiye Patent ve Marka Kurumu kayıtları. https://www.ci.gov.tr/Statistics.

Anonymous, 2011. Tomato and pepper taste test results, tomato ratings, http://aes.missouri.edu, 2011.

Baykal, Ö.B., Çetin, H. ve Sencan, M. 1983. Bazı domates çeşitlerinin sıraya uygunluğu üzerine bir araştırma. Bahçe Dergisi, 12(1):55-64.

Cemeroğlu, B. 2010. Gıda Analizleri, Genişletilmiş İkinci Baskı, Nobel Akademik Yayıncılık, Ankara.

Eşiyok, D., Boztok, K., Sen, F., Ugur, A. ve Bozokalfa, M.K. 2004. Bazı sera domates çeşitlerinin verim kalite ve depolama özelliklerinin belirlenmesi. E.Ü. Ziraat Fakültesi Dergisi, 41(2): 9-17.

Güler, E., Gürler, A.Z., Nabalı, B. ve Ayyıldız, B. 2016. Coğrafi İşaretlerin Kırsal Kalkınma Açısından Değerlendirilmesi: Tokat İli Örneği. XII. Tarım Ekonomi Kongresi, 25-27 Mayıs, 1049-1058.

Ilıcalı, G. 2005. Coğrafi İşaretler, Coğrafi İşaretlerde Denetim ve Denetimde İşaretlerin" Kullanımı: İzmit Pişmaniyesi Örneği, Anatolia: Turizm Araştırmaları Dergisi, 21(2): 243-254.

Josling, T. 2005, What's in a name? The economics, law and politics of geographical indications for foods and beverages, paper presented to the Institute for International Integration Studies, Trinity College, Dublin, $28 \mathrm{~s}$.

Kaya, S. 2012. Yerel sofralık domates populasyonlarının organik tarıma uygunlukları ve organik çeşit geliştirme amacıyla kullanım olanakları üzerine araştırmalar. Doktora Tezi, Ege Üniversitesi, Fen Bilimleri Enstitüsü, Bahçe Bitkileri Anabilim Dalı, Bornova, İzmir. 111 s.

Lopez Camelo, A.F. ve Gómez, P.A. 2004. Comparison of color indexes for tomato ripening. Horticultura Brasileira, Brasília, 22(3), 534-537.

McCormack, H. 2004. Tomato seed production. An organic seed production manual for seed growers in the Mid-Atlantic and Southern U.S. Creative Commons, 559 Nathan Abbott Way, Stanford, California 94305, USA. P.15.

Özbay, N., Ateş, K. 2015. Bingöl ilii Ekolojik Şartlarına Uygun Sofralık Domates Çeşitlerinin Belirlenmesi. Türk Tarım ve Doğa Bilimleri Dergisi 2(2): 226-236.

Özbay, N., Sarıyer, T. ve Korkmaz, A. 2012. Afyonkarahisar ili ekolojik şartlarına uygun sofralık domates çeşitlerinin Belirlenmesi. Türk Doğa ve Fen Dergisi, 1(2): 64-70.

Sağlam, N. ve Taşova, C. 2017. Tokat koşullarında ana ve ikinci ürün yetiştiriciliğine uygun sanayilik domates çeşitlerinin belirlenmesi. Akademik Ziraat Dergisi, 6(Özel Sayı) :4146.

Şahin, A. ve Meral, Y. 2012, Türkiye'de Coğrafi Işaretleme ve Yöresel Ürünler. Türk Bilimsel Derlemeler Dergisi, 5(2): 88-92.

Şahin, G. 2011. Türkiye'nin Coğrafi İşaretleri. Uluslararası Katılımlı Coğrafya Kongresi, 7 10 Eylül 2011. İstanbul. 
Tepe, S. 2008. Coğrafi İşaretlerin Ekonomik Etkileri. Uzmanlık Tezi, Türk Patent Enstitüsü Markalar Dairesi Başkanlığı, Ankara, 4-62s.

Vural, H., Eşiyok, D. ve Duman, İ. 2000. Kültür sebzeleri. Ege Üniversitesi Basımevi, İzmir, $440 \mathrm{~s}$. 